
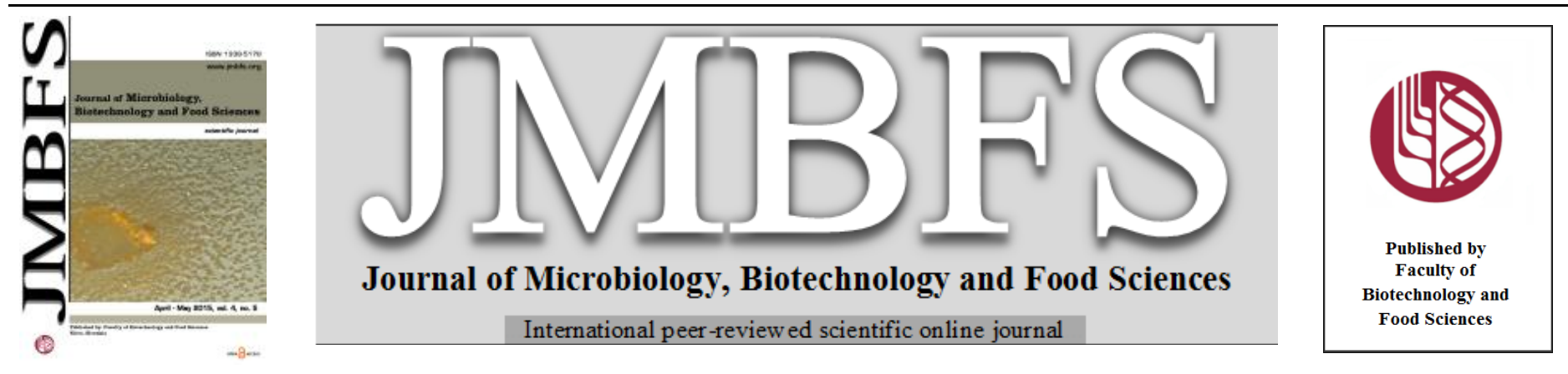

\title{
OPTIMIZATION OF VEGETABLE WASTES FOR LACTIC ACID PRODUCTION: A LABORATORY SCALE APPROACH
}

\author{
Sailaja Daharbha ${ }^{1}$, Mohit S. Mishra ${ }^{2}$, Rakesh K. Meena ${ }^{3}$, Roshini Meghanani ${ }^{2}$, Prashant Shukla ${ }^{2, *}$
}

\author{
$\operatorname{Address(es):~}$ \\ ${ }^{1}$ GokarajuRangaraju Institute Of Engineering \& Technology, Hyderabad, India \\ ${ }^{2}$ Raipur Institute of Technology, Raipur, India \\ ${ }^{3}$ Aditya Biotech Lab and Research, Raipur, India
}

*Corresponding author: prashant19782000@gmail.com

doi: $10.15414 / j m b f s .2015 .4 .5 .452-455$

ARTICLE INFO

Received 7. 10. 2014

Revised 17. 12. 2014

Accepted 23. 2. 2015

Published 1. 4. 2015

$\underline{\text { Regular article }}$

open $\odot$ access

\section{ABSTRACT}

Vegetables wastes are organic materials which are not utilized as vegetables and are discarded at all stages of production, processing and marketing. These wastes form a major part of municipal solid wastes and are cause of foul smell and growth of microorganisms due to their high organic contents. The vegetable wastes can be utilized in many different ways to produces different products. We have shown that they can be utilized for production of lactic acid using anaerobic digestion. The 2nd day was the optimum day for recovery of lactic acid while 1:1 ratio of slurry and water was found to the best ratio for production of lactic acid from vegetable wastes. Effect of salts on lactic acid was also studied and it was found that the production decreased in all the concentrations of salts.

Keywords: Vegetable wastes, lactic acid, fermentation, optimization

\section{INTRODUCTION}

Vegetable wastes form part of huge amount of solid wastes generated all over the world daily. In the world, for total production of fruits and vegetables by India is in second number. Nearly $10 \%$ to $14 \%$ of fruits and vegetables are produced by India (Das and Mondal, 2013). The parts of vegetables not used are discarded as wastes. Vegetable wastes are generated from field to markets at all level of processing and transport. These wastes form part of organic wastes which are major source of foul smell originating from large municipal dumping sites and landfills(Viturtiaet al., 1989; Misi and Foster, 2002). It has been reported that such wastes can be utilized in various ways so to reduce the load of organic matter in landfills and dumping sites. Anaerobic digestion provides proficient recovery of resource and its impact on environmental is lesser therefore it is evaluated favorably with alternative waste management processes, such as incineration, landfill and composting (Foresti, 2001; McCarty, 2001; Gilzen, 2002; Lema and Omil, 2001; van Lieret al., 2001; De baere, 2000; Suh and Rousseaux, 2002). Production of organic acids has been tried using organic wastes materials like kitchen wastes previously. Utilization of wastes for production of useful production is a way to reduce load at dumping sites and it also provides a better solution for production of useful chemicals in a way which is easy and cheap compared to direct chemical processes.

The process of fermentation of wastes is completed by different set of microorganisms which colonize the fermentation broth in succession(Knolet al., 1978). Initially at the start of fermentation hydrolysis takes places where macromolecules like carbohydrates and proteins are converted in to monomers like amino acids and monosaccharides. When there is sufficient quantity of simpler organic molecules is accumulated in the fermentation broth then the process of acidogenesis occurs while hydrolysis is slowed down due to feedback control of the small molecules like glucose on production of enzymes like cellulases from microorganisms. The acidogenesis causes the $\mathrm{pH}$ of the broth to decrease which is not suitable for most of the hydrolyzing microorganisms which subsequently are removed from the broth and more acidophilic microorganisms colonize the broth. With continuation of hydrolysis more and more organic acid accumulates and then the process of methanogenesis occur which form methane from the organic acids formed during acidogenesis.

The optimum production of organic acids can be taken at the time of acidogenesis phase of fermentation. Before this there is not much hydrolysis of macromolecules and during methanogenesis the organic acids are converted into methane therefore decreasing the quantity of organic acids in the broth. To optimize production of organic acids from wastes protein and carbohydrates should be quantified in the fermentation broth to determine the extent of hydrolysis along with the quantification of organic acid. This will help in exact determination of the time up to which hydrolysis takes places as during the stage where hydrolysis dominates the amount of organic acid will not be sufficient. Like wise at the onset of methanogenesis the amount of organic acid will start decreasing as it will be converted in to methane so recovery of organic acids should be done in the stage of acidogenesis for optimum recovery of organic acids from the fermentation broth.

The current study was performed to optimize the period of best lactic acid production along with the best ratio of slurry and water. We also studied the effect of slats on the production of lactic acid.

\section{MATERIALS AND METHODS}

Vegetable wastes form a large part of organic waste material which is dumped in landfills in the form of solid wastes. It causes problem as it is readily converted into simpler products by microorganisms in such landfills. Fermentation of such organic wastes for production of organic acids can be a reliable method for eliminating the problem of waste disposal concerning vegetable wastes. Vegetable wastes were collected from Shastri Market, Raipur, Chhattisgarh, India. The current study was done to optimize the period for lactic acid production from vegetable wastes. Proteins and carbohydrates were determined in the wastes before fermentation and at intervals where lactic acid production was estimated. Proteins and carbohydrates were determined during lactic acid production to estimate the level of hydrolysis during fermentation. As the level of proteins and carbohydrates will decrease the lactic acid production will increase. The study also included isolation of microorganisms present in the fermentation broth and identification of these using PIBWIN. The downstream processing and recovery of the product was also achieved.

A fermentor with capacity of 15 litres was used to achieve anaerobic digestion of vegetable wastes. The temperature was set to $37^{\circ} \mathrm{C}$. The vegetable wastes were poured into the fermentor and incubated at $150 \mathrm{rpm}$. The vegetable wastes were incubated in the fermentor for 6 days. The fermented slurry was removed after every 24 hour to estimate the $\mathrm{pH}$, protein, carbohydrate, TDS, TSS, COD and TKN and lactic acid concentrations. 


\section{Protein and carbohydrate estimation}

Vegetable waste slurry was used to determine proteins and carbohydrates by using standard methods i.e. Lowery method (for proteins) and anthrone (for carbohydrates) method.

Lowry method used for protein estimation is as follows: $0.5 \mathrm{ml}$ sample was taken in a test tube and $0.7 \mathrm{ml}$ of Lowry's solution was added to the (Lowry's solution $=\operatorname{sol} \mathrm{A}+\operatorname{sol} \mathrm{B}+\operatorname{sol} \mathrm{C}$ with a ratio of 100:1:1. The incubation was carried out in dark for about 20 minutes. Then, $0.5 \mathrm{ml}$ of Folin's reagent was added, vortexed immediately and incubated once more for $30 \mathrm{~min}$ or longer at room temperature. The absorbance of the color developed was taken at $750 \mathrm{~nm}$.

The carbohydrate was analyzed for vegetable wastes by anthrone method. $1 \mathrm{ml}$ of sample was taken in a test tube and $2 \mathrm{ml}$ of chilled $75 \%$ sulphuric acid was added and vortexed. To this mixture, $4 \mathrm{ml}$ of anthrone solution was added and placed in the water bath and boil it at $100{ }^{\circ} \mathrm{C}$ for $15 \mathrm{~min}$. The mixture was cooled down to room temperature and the absorbance was measured at $578 \mathrm{~nm}$.

\section{Estimation of Total Dissolved Solids}

A well mixed sample was filtered using a standard glass fiber filter and the filtrate was evaporated to dryness in the weight dish and dried to constant weight at $180^{\circ} \mathrm{C}$ in a vacuum oven. The increase is dish weight after drying represented the total dissolved solids.

\section{Estimation of Total Suspended Solids (TSS)}

The sample was mixed thoroughly and filtered through a previously weight filter membrane. The residue obtained on the paper was dried at 103 to $105^{\circ} \mathrm{C}$. Total suspended solids are represented by the increase in the weight of the filer paper. To obtain an estimate of total suspended solids, the difference in the values of total dissolved solids and total solids was calculated.

\section{Estimation of COD}

The value of chemical oxygen demand determines the organic pollution which is the measurement of oxygen required to oxidize the waste chemically. To estimate COD the following procedure was followed: Supernatant of sludge sample was taken in COD tubes and $0.3 \mathrm{ml}$ mercury sulphate and $2.3 \mathrm{ml}$ of solution of potassium dichromate with sulphuric acid were added. Then the total sample solution and blank solution was kept in COD thermoreactor for 120 mins at 148 degree Celsius and cooled to room temperature. Then the optical density is measured by colorimetric method. The COD is calculated by standard calibration curve.

\section{Estimation of Total Kjeldahl Nitrogen}

Total Kjeldahl Nitrogen was estimated by the method Johri et al., 2000.

\section{Bacterial isolation}

Isolation of bacteria was performed by dilution plate technique (Waksman and Fred, 1922) and direct plate technique, using nutrient agar medium (peptone $5 \mathrm{~g}$; beef extract $3 \mathrm{~g}$; $\mathrm{NaCl} 5 \mathrm{~g}$; agar $20 \mathrm{~g}$; distilled water $1000 \mathrm{ml}$; $\mathrm{pH} 7.2$ ). $1 \mathrm{ml}$ of vegetable waste sample was taken in $9 \mathrm{ml}$ of sterile distilled water and mixed to a homogenous solution. Different dilutions of sample were prepared as $10^{-3}, 10^{-5}$ and $10^{-6}$ and were applied onto agar plates. The agar plates were prepared by adding approx. of $20 \mathrm{ml}$ melted medium. After gently rotating, the plates were incubated at 37 degree Celsiusfor 24 to $48 \mathrm{~h}$. Selected colonies of bacteria were transferred from mother culture plates onto respective agar plates, incubated at 37 degree Celsiusfor 24-48h.Pure cultures were stored at 4 degree Celsius until further examination. Bacterial colonies were characterized morphologically, biochemically and physiologically. For identification of bacteria isolated from fermented broth PIBWin (Probabilistic identification of bacteria) was used which is one of the databases developed for the identification of bacteria based on numerical taxonomy. In this data based equal weight is given to various cultural, morphological, physiological and biochemical features (Bryant, 2004)

\section{Optimum incubation period}

The optimum incubation period was determined for production of lactic acid from vegetable wastes. The wastes were brought in to the laboratory and washed with distilled water to remove the dirt. The $1: 1 \mathrm{w} / \mathrm{v}$ of vegetable wastes and distilled water was taken and slurry made using a grinder. The slurry was poured in to $250 \mathrm{ml}$ flasks and kept in shaker incubator for fermentation. At 24 hours interval a single flask was removed from the incubator and lactic acid produced in it was determined.

\section{Estimation of lactic acid}

Lactic acid production from vegetable wastes was determined by titrating the culture broth against $0.1 \mathrm{~N} \mathrm{NaOH}$ using phenolphthalein as indicator. $25 \mathrm{ml}$ of culture broth was taken from the fermented broth in a flask and boiled for 2 minutes to remove air. $\mathrm{NaOH}$ solution was added with continuous shaking till there was persistent pink color formation. Amount of lactic acid was determined as the quantity of $\mathrm{NaOH}$ utilized in titration multiplied by 90.08 . The lactic acid produced was reported in $\mathrm{mg}$ using method given by (Omemu and Faniran, 2011).

\section{Effect of ratio of slurry and water}

Different ratio of waste slurry and water were tested to determine optimum ratio for lactic acid production. The slurry was then mixed with different quantities of water to dilute it different ratios (1:0.75, 1:0.50 and 1:0.25). The slurry of different ratios were poured in $250 \mathrm{ml}$ flasks and kept in shaker incubator for incubation for 48 hours.

\section{Effect of salts}

Similarly to study the effect of salts on production of organic acids different concentrations ( $1 \mathrm{M}, 0.75 \mathrm{M}, 0.50 \mathrm{M}$ and $0.25 \mathrm{M})$ of $\mathrm{NaCl}$ and $\mathrm{CuSO} 4$ were used in the best ratio found in the earlier study.

\section{Recovery of lactic acid}

To recover lactic acid from fermented broth $20 \mathrm{ml}$ of broth was removed from the fermentor each time. The sample was drawn was used to estimated various parameters described above and was also used to recover the lactic acid. To recover lactic acid the broth was filtered through Whatman filter paper and then $500 \mathrm{ml}$ of solvents (butanol, chloroform) were used to extract the lactic acid. To recover the solvent containing the acid the solvent containing the crude sample was extracted using Soxhlet apparatus. The temperature of extraction was set just above the billing point of the solvent. After the completion of the extraction the extracted solvent was used to recover lactic acid by evaporating the solvent containing the recovered acid. The recovered acid was weighed after evaporation of the solvent.

\section{RESULTS AND DISCUSSIONS}

Vegetable wastes are organic wastes which are used by microorganisms for their growth and in doing so they produce variety of products. We utilized vegetable wastes for optimization of ratio of slurry and water for lactic acid production.

The proteins and carbohydrates were estimated from the vegetables wastes and of the fermented broth at 24 hour intervals. The results of the values of carbohydrates and proteins are given in table 1 and 2 . Initial values of these macromolecules kept on decreasing at were lowest on the 2 day of fermentation. The $\mathrm{pH}$ of the fermentation broth also decreased with time (Table-6). The values of TSS initially was $162.5 \mathrm{~g} / \mathrm{l}$ but it decreased to $61 \mathrm{~g} / \mathrm{l}$ on $4^{\text {th }}$ day and it kept on decreasing during all the process of extraction and recovery process of lactic acid from the fermented sample (Table-4 and 7).During fermentation process the total dissolved solids kept on increasing and COD value kept on decreasing for the whole period of experiment (Table- 8 and 9).During the recovery process the TKN value were observed in decreasing order with every step(Table-10).

Total of five bacteria were isolated from the fermented broth and using PIBWIN we identified them as Lactobacillus Casei, Lactobacillus acidophilus, Bacillus megaterium, Pseudomonas fluorescence and E. coli. The biochemical analysis of the bacteria isolated from fermented wastes is given elsewhere (Mishra $\boldsymbol{e t}$ al., 2012).

It was determined in our study those 48 hours incubation was the optimum period for lactic acid production. At 24 hours not enough lactic acid was produced due to incomplete hydrolysis of the vegetable wastes. After 48 hours the process of acidogenesis either slows down or stops with methanogenesis taking over which also utilizes lactic acid produced for methane production either directly or through conversion of lactic acid into acetate. At 48 hours hydrolysis is significant and methanogenesis does not starts therefore we can recover most of lactic acid produced at this time interval. The highest amount of lactic acid produced after 48 hours of incubation was $3.915 \mathrm{~g}$ (Table-3)of different ratios of vegetable waste slurry and water taken for production of lactic acid it was found that 1:1 ratio of vegetable waste slurry and water was best for lactic acid production at $4.948 \mathrm{~g}$ (Table-4). This was high when compared to the results given by Omemu and Faniran (2011) from $S$. thermophillus which produced $2.18 \mathrm{~g} / \mathrm{l}$ after 36 hours of fermentation using maize products. Similarly Shiphrah et al. (2013) reported $0.823 \mathrm{~g} / 1$ to $0.634 \mathrm{~g} / 1$ production of lactic acid using different bacterial strains in whey water.As the dilution of slurry increased the quantity of lactic acid produced decreased. We established in this work that for production of lactic acid in higher amounts the slurry should not be diluted as the dilution increases the space between the waste particles which reduces the effective surface area for the microorganisms to act. 
The effect of two salts i.e. $\mathrm{NaCl}$ and $\mathrm{CuSO} 4$ was also studied of the different concentrations used for lactic acid production in 1:1 ratio of vegetable waste slurry and water it was found that as the concentration of slats increased the production of lactic acid decreased for both the salts. Through this we have established that for lactic acid production from vegetable wastes there is no requirement of additional salts to be put from outside. The results for lactic acid production in $\mathrm{NaCl}$ are given in Table-5. As the lactic acid production with $\mathrm{CuSO} 4$ was negligible we have not reported it.

Table 1 Change in Carbohydrate with time (During fermentation)

\begin{tabular}{lcc}
\hline SI.No & Day & Carbohydrate $(\mathbf{m g} / \mathbf{L})$ \\
\hline 1 & 0 & $614.40 \pm 0.58$ \\
\hline 2 & 1 & $609.27 \pm 0.78$ \\
\hline 3 & 2 & $597.72 \pm 0.49$ \\
\hline 4 & 3 & $513.16 \pm 0.60$ \\
\hline
\end{tabular}

Legend:Values are mean \pm SE $(n=6)$. Values are statistically significant at $P \leq 0.05$ as determined by ANOVA followed by Duncan's test of significance

Table 2 Change in Protein with time (During fermentation)

\begin{tabular}{lcc}
\hline Sl.No & Day & Protein $(\mathbf{m g} / \mathbf{L})$ \\
\hline 1 & 0 & $322.79 \pm 0.48$ \\
\hline 2 & 2 & $320.01 \pm 0.39$ \\
\hline 3 & 1 & $289.10 \pm 0.29$ \\
\hline 4 & 3 & $370.44 \pm 0.43$ \\
\hline
\end{tabular}

Legend:Values are mean $\pm \mathrm{SE}(\mathrm{n}=6)$. Values are statistically significant at $\mathrm{P} \leq 0.05$ as determined by ANOVA followed by Duncan's test of significance

Table 3 Lactic acid production on different days with 1:1 ratio of wastes and water (w/v)

\begin{tabular}{lccc}
\hline Sl. No & Day / ratio & Volume of alkali & $\begin{array}{c}\text { Lactic acid } \\
\text { produced }\end{array}$ \\
\hline 1 & Zero & $3.6 \mathrm{ml}$ & $0.024 \mathrm{~g}$ \\
\hline 2 & First & $16.9 \mathrm{ml}$ & $1.521 \mathrm{~g}$ \\
\hline 3 & Second & $43.5 \mathrm{ml}$ & $3.915 \mathrm{~g}$ \\
\hline 4 & Eight & $33.0 \mathrm{ml}$ & $2.97 \mathrm{~g}$ \\
\hline 3 & Fourth & $15.6 \mathrm{ml}$ & $1.404 \mathrm{~g}$ \\
\hline
\end{tabular}

Table 4 Determination of lactic acid production using different ratio of slurry and water after 48 hours of incubation

\begin{tabular}{lccc}
\hline Sl. No & Day / ratio & Volume of alkali & $\begin{array}{c}\text { Lactic acid } \\
\text { produced }\end{array}$ \\
\hline 1 & $1: 1$ & $54.5 \mathrm{ml}$ & $4.948 \mathrm{~g}$ \\
\hline 2 & $0.75: 1$ & $25.5 \mathrm{ml}$ & $2.315 \mathrm{~g}$ \\
\hline 3 & $0.50: 1$ & $07.4 \mathrm{ml}$ & $0.671 \mathrm{~g}$ \\
\hline 4 & $0.25: 1$ & $0.0 \mathrm{ml}$ & $0.09 \mathrm{~g}$ \\
\hline
\end{tabular}

$\underline{\text { Table } 5 \text { Production of lactic acid with } \mathrm{NaCl}}$

\begin{tabular}{lccc}
\hline $\begin{array}{l}\text { Sl. } \\
\text { No }\end{array}$ & Normality of NaCl & Volume of alkali & $\begin{array}{c}\text { Lactic acid } \\
\text { produced }\end{array}$ \\
\hline 1 & $1 \mathrm{~N} \mathrm{NaCl}$ & $2.6 \mathrm{ml}$ & $2.92 \mathrm{~g}$ \\
\hline 2 & $0.75 \mathrm{~N} \mathrm{NaCl}$ & $2.0 \mathrm{ml}$ & $2.19 \mathrm{~g}$ \\
\hline 3 & $0.5 \mathrm{~N} \mathrm{NaCl}$ & $5.0 \mathrm{ml}$ & $1.462 \mathrm{~g}$ \\
\hline 4 & $0.25 \mathrm{~N} \mathrm{NaCl}$ & $3.1 \mathrm{ml}$ & $0.731 \mathrm{~g}$ \\
\hline
\end{tabular}

Table 6 Change in $\mathrm{pH}$ with time (During fermentation)

\begin{tabular}{lccc}
\hline S. No. & Number of Days & Initial pH & Final pH \\
\hline 1 & 1 & 6 & $3.43 \pm 0.23$ \\
\hline 2 & 2 & 6 & $3.41 \pm 0.05$ \\
\hline 3 & 3 & 6 & $3.35 \pm 0.09$ \\
\hline 4 & 4 & 6 & $3.28 \pm 0.02$ \\
\hline
\end{tabular}

Legend:Values are mean $\pm \mathrm{SE}(\mathrm{n}=6)$. Values are statistically significant at $\mathrm{P} \leq 0.05$ as determined by ANOVA followed by Duncan's test of significance

The fermentation process was initiated with $\mathrm{pH} 4.96$. The process was completed at $37^{\circ} \mathrm{C}$ at $150 \mathrm{rpm}$
Table 7 Change in TSS with time (During fermentation and Down Stream Processing)

\begin{tabular}{lcc}
\hline S. No. & State of Condition & Change in TSS value (g/l) \\
\hline 1 & 0 day & $162.54 \pm 0.15$ \\
\hline 2 & 4 day & $61.72 \pm 0.10$ \\
\hline 3 & Freezing and thawing & $18.56 \pm 0.02$ \\
\hline 4 & After extraction & $18.50 \pm 0.06$ \\
\hline 5 & After Freezing & $10.04 \pm 0.05$ \\
\hline 6 & After distillation & $9.95 \pm 0.20$ \\
\hline 7 & After Evaporation & $60.02 \pm 0.04$ \\
\hline
\end{tabular}

Legend:Values are mean $\pm \mathrm{SE}(\mathrm{n}=6)$. Values are statistically significant at $\mathrm{P}<0.05$ determined by ANOVA followed by Duncan's test of significance

The fermentation process was initiated with $\mathrm{pH} 4.96$. The process was completed at $37^{\circ} \mathrm{C}$ at $150 \mathrm{rpm}$

Table 8 Change in TDS with time (During fermentation)

\begin{tabular}{lcc}
\hline S.No & Day & T.D.S (ppt) \\
\hline 1 & 0 & $1.65 \pm 0.04$ \\
\hline 2 & 2 & $2.005 \pm 0.03$ \\
\hline 3 & 4 & $2.16 \pm 0.04$ \\
\hline 4 & 6 & $2.76 \pm 0.08$
\end{tabular}

Legend:Values are mean $\pm \mathrm{SE}(\mathrm{n}=6)$. Values are statistically significant at $\mathrm{P} \leq 0.05$ as determined by ANOVA followed by Duncan's test of significance

Table 9 Change in COD with time (During fermentation)

\begin{tabular}{lcc}
\hline S. No. & Fermentation Days & Change in COD Value (mg/l) \\
\hline 1 & 0 & $1726.53 \pm 0.08$ \\
\hline 2 & 2 & $1662.40 \pm 0.09$ \\
\hline 3 & 4 & $1613.12 \pm 0.12$ \\
\hline 4 & 6 & $1562.45 \pm 0.20$
\end{tabular}

Legend:Values are mean $\pm \mathrm{SE}(\mathrm{n}=6)$. Values are statistically significant at $\mathrm{P} \leq 0.05$ as determined by ANOVA followed by Duncan's test of significance

Table 10Change in TKN with each step of recovery processes

\begin{tabular}{lcc}
\hline S. No. & Stages & TKN value (\%) \\
\hline 1. & Vegetable Waste Day (0) & 18.426 \\
\hline 2. & Vegetable Waste Day (4) & 0.385 \\
\hline 3. & After freezing and Thawing & 0.284 \\
\hline 4. & After extraction & 0.277 \\
\hline 5. & After filtration & 0.205 \\
\hline 6. & After Distillation & 0.197 \\
\hline 7. & After Evaporation & 0.125 \\
\hline
\end{tabular}

\section{CONCLUSION}

The use of vegetable wastes can be an important source of organic acids and specially lactic acid. As the importance of lactic acid is far greater than most of the organic acids we have developed a method to produce lactic acid from vegetable wastes. When the vegetable wastes will be utilized for production of lactic acid on large scale it will help in reducing environmental pollution. In the current study we have shown that the amount of carbohydrates and proteins in changes with time during fermentation which is a good indicator of the fact that fermentation is progressing as required. Also we have shown that there is no need of adding any salts for increase in the production of lactic acid in the case of its production from vegetable wastes.

Statistical Analyses: Statistical analyses was done using SPSS 16 statistical software. Mean along with standard error was determined by ANOVA (Analysis of Variance) followed by Duncan's test of significance.

Acknowledgement: The authors would like to acknowledge the support of Chhattisgarh Council of Science and Technology for their financial support.

\section{REFERENCES}

BRYANT, T. N. 2004 PIBWIN- software for probabilistic identification $J$ ApplMicrobiol 97(6), 1326-1327 http://dx.doi.org/10.1111/j.13652672.2004.02388.x

DAS, A., MONDAL, C. 2013.Studies on the Utilization of Fruit and Vegetable

Waste for Generation of Biogas. International Journal of Engineering and Science, 3(9), 24-32 
DE BAERE, L. A.2000. Anaerobic digestion of solid waste: state-of-the-art

Water SciTechnol, 41, 283-90.

FORESTI, E.2001.Perspective on anaerobic treatment in developing countries. Water SciTechnol, 44, 141-148

GILZEN, H. J.2002. Anaerobic digestion for sustainable development: a natural approach. Water SciTechnol, 45, 321-328

KNOL, W., VANDER MOST, M. M., WAART, J. 1978.Biogas production by anaerobic digestion of fruit and vegetable waste.A preliminary study.J Sci Fed Agric, 29,822-30 http://dx.doi.org/10.1002/jsfa.2740290913

LEMA, J. M., OMIL, F. 2001.Anaerobic treatment: a key technology for a sustainable management of wastes in Europe.Water SciTechnol 44, 133-140

MCCARTY, P. L.2001.The development of anaerobic treatment and its future.

Water Sci Technol, 44, 149-156

MISI, S. N., FORSTER, C. F.2002.Semi-continuous anaerobic co-digestion of agro-waste. Environ Technol, 23, 445-51

OMEMU, A.M., FANIRAN, O.W. 2011.Assessment of the antimicrobial activity of lactic acid bacteria isolated from two fermented maize products -ogiand kunnu-zaki. Mal. J. Microbiol, 7(3), 124-128

SHIPHRAH, V. H., SAHU, S., THAKUR, A. R., CHAUDHURI, S. R. 2013 Screening of bacteria for lactic acid production from whey water American

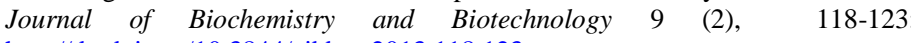
http://dx.doi.org/10.3844/ajbbsp.2013.118.123

SUH, Y. J., ROUSSEAUX, P. 2002. An LCA of alternative wastewater sludge treatment scenarios.ResourConserRecyc, 35,191-200 http://dx.doi.org/10.1016/S0921-3449(01)00120-3

VAN LIER, J. B., TILCHE, A., AHRING, B. K. 2001. New perspectives in anaerobic digestion. Water SciTechnol 43, 1-18

VITURTIA, A., MATA-ALVAREZ, J., CECCHI, F., FAZZINI, G.1989.Twophase anaerobic digestion of a mixture of fruit and vegetable wastes.Biol Wastes 29, 189-99

WAKSMAN, S. A., FRED, E. B. 1922 A Tentative Outline of the Plate Method for Determining the Number of Micro-Organisms in the Soil Soil Science 14(1), 27-28 http://dx.doi.org/10.1097/00010694-192207000-00004 